\title{
Development and characterization of $\alpha$-tricalcium phosphate/monocalcium aluminate composite bone cement
}

\author{
Loreley Morejón-Alonso $^{1 *}$, Raúl García Carrodeguas ${ }^{2}$, Luis Alberto dos Santos ${ }^{3}$ \\ ${ }^{1}$ General Chemistry Department, Chemistry Faculty, Havana University, Havana, Cuba \\ ${ }^{2}$ Ceramic Department, Instituto de Cerámica y Vidrio-CSIC, Madrid, Spain \\ ${ }^{3}$ Engineering School, Materials Department, Universidade Federal do Rio Grande do Sul, Porto Alegre, Brazil \\ Email: ${ }^{*}$ Imorejon@,fq.uh.cu, ${ }^{*}$ loreley.morejon@ufrgs.br
}

Received 6 June 2012; revised 5 July 2012; accepted 13 July 2012

\begin{abstract}
Calcium phosphate cements have received much attention in recent decades owing to their biocompatibility, in situ handling, and shaping abilities. However, their low initial mechanical strength is still a major limitation. On the other hand, calcium aluminate cements (CACs) set fast and have a high initial strength and good corrosion resistance in contact with body fluids, making them excellent dental restorative materials. Therefore, the chemical, mechanical and biological properties of new-TCP/CA cement after aging in simulated body fluid (SBF) were investigated. The results indicated that the composites have setting times not appropriated for immediate applications and have degradation rates higher than those of the traditional CPCs. Moreover, the compressive strength of composite was lower than $5 \mathrm{MPa}$ and did not increase with SBF immersion. However, the $\alpha$-TCP/CA composites showed a higher bioactivity at early stages and were not only more biocompatible but also more noncytotoxic.
\end{abstract}

Keywords: Calcium Phosphate Cements; Calcium Aluminate Cements; Hydroxyapatite; In Vitro

\section{INTRODUCTION}

Calcium phosphate cements (CPCs) are a clinical alternative to traditional bioceramics because they are easy to handle and shape, they mold themselves well to the contours of defective surfaces, and set in situ in the bone cavity to form a solid restoration [1]. Since they were developed in the mid-1980s, CPCs have also attracted great interest due to their chemical similarity to the mineral phase of bone tissue and their good osteoconductivity [2].

One of the most important formulations is based on $\alpha$-tricalcium phosphate $\left[\alpha-\mathrm{Ca}_{3}\left(\mathrm{PO}_{4}\right)_{2} ; \alpha\right.$-TCP], which sets

"Corresponding author. in situ and forms a calcium-deficient hydroxyapatite $\left[\mathrm{Ca}_{9}\left(\mathrm{HPO}_{4}\right)\left(\mathrm{PO}_{4}\right)_{5}(\mathrm{OH}) ; \mathrm{CDHA}\right]$ when hydrated [3]. However, it is not very strong under compression [4] and its mechanical strength is low when compared to that of cortical bone [5] limiting its application to areas subjected to low mechanical loads [6].

In view of the excellent bioresorbability of CDHA, researchers have focused their efforts on overcoming the mechanical weakness of calcium phosphate cements by using different fillers, fibers and reinforcing additives that lead to the formation of various multiphase composites, based on the idea that the filler in the matrix may eliminate crack propagation [7]. Nevertheless, the presence of fillers prevents bone ingrowths into pores and produces a denser cement with a slower resorption rate and hence a slower bone substitution [8]. Therefore, it is difficult to increase the strength of these cements without negatively affecting other properties.

In the late 1990s, the Swedish company Doxa Certex $\mathrm{AB}$ proposed the use of calcium aluminate cements (CACs) as dental restorative materials in place of amalgam [9], and today the use of CACs has extended to several orthopedic applications [10,11]. The calcium aluminate system has two inherent features that make it suitable for load-bearing applications: fast setting and high consumption and turnover of water during the setting and reaction. The high water turnover gives the system a potentially high strength, several times that of normal CPCs. Moreover, CACs have good corrosion resistance in contact with body fluids and are biocompatible since the amount of $\mathrm{Al}$ ion leakage is very low $[12,13]$. In these materials, the main phase commonly used is monocalcium aluminate $\left[\mathrm{CaAl}_{2} \mathrm{O}_{4}, \mathrm{CA}\right]$ due to its optimal reaction rate compared with the other phases.

Although some calcium phosphates, as $\beta$-tricalcium phosphate, are used in combination with CACs in order to induce some biological activity in the resultant composites [14], the use of CA as a reinforced additive of traditional CPCs is not documented. Thus, the aim of this 
work was to design and study new $\alpha$-TCP/CA formulations intended for biomedical applications. To this end, the chemical, mechanical and biological properties of $\alpha$-TCP/CA cement after aging in simulated body fluid were investigated.

\section{MATERIALS AND METHODS}

\subsection{Materials}

$\alpha$-TCP was prepared through solid state reaction, heating the appropriate mixture of $\mathrm{Ca}_{2} \mathrm{HPO}_{4} \cdot 2 \mathrm{H}_{2} \mathrm{O}$ (Extra Pure, Dyne ${ }^{\circledR}$ ) and $\mathrm{CaCO}_{3}$ (Extra Pure, Nuclear) at $1300^{\circ} \mathrm{C}$ for 5 $\mathrm{h}$ followed by quenching in air [15]. After calcination, the product was wet milled for $4 \mathrm{~h}$ in a polyethylene jar with alumina balls using an alcoholic medium (anhydrous ethanol, 99.5\%, Cromoline) to an average particle size inferior to $10 \mu \mathrm{m}$. The powder was composed of a mixture of $82 \%$ of $\alpha$-TCP and $18 \%$ of $\beta$-TCP [16].

$\mathrm{CA}$ was synthesized through Pechini technique [17] using high purity $\mathrm{Ca}\left(\mathrm{NO}_{3}\right)_{2} \cdot 4 \mathrm{H}_{2} \mathrm{O}$ (Synth, PA-ACS) and $\mathrm{Al}\left(\mathrm{NO}_{3}\right)_{3} \cdot 9 \mathrm{H}_{2} \mathrm{O}$ (Synth, PA-ACS) in the presence of citric acid $\left(\mathrm{C}_{6} \mathrm{H}_{8} \mathrm{O}_{7} \cdot \mathrm{H}_{2} \mathrm{O}\right)$ (Synth, PA-ACS) and ethylene glycol $\left(\mathrm{C}_{2} \mathrm{H}_{6} \mathrm{O}_{2}\right)$ (Synth, PA). Suitable amounts of nitrate salts were dissolved, followed by the addition of citric acid and ethylene glycol. After gelification, the gel was heated at $150^{\circ} \mathrm{C}$ for $24 \mathrm{~h}$ and calcined at $400^{\circ} \mathrm{C}$ for $2 \mathrm{~h}$ to form the powder precursor, which was heat-treated at $1000^{\circ} \mathrm{C}$ for $3 \mathrm{~h}$. In order to obtain powders with similar average particle size, the same milling treatment as in the case of $\alpha$-TCP was used.

\subsection{Preparation of Composite Samples}

Synthesized CA $\left(7 \mu \mathrm{m} ; 11.88 \mathrm{~m}^{2} / \mathrm{g}\right)$ was mixed in powder ratios of $0,5.0$ and 10.0 mass \% with $\alpha$-TCP (10.71 $\mu \mathrm{m} ; 5.52 \mathrm{~m}^{2} / \mathrm{g}$ ). The liquid phase was a sodium phosphate buffer prepared from $\mathrm{NaH}_{2} \mathrm{PO}_{4}$ and $\mathrm{Na}_{2} \mathrm{HPO}_{4} \cdot 12 \mathrm{H}_{2} \mathrm{O}$ and the liquid-to-powder ratios $(\mathrm{L} / \mathrm{P})$ employed were 0.4 , 0.44 and $0.46 \mathrm{ml} / \mathrm{g}$, respectively. Each powder sample was carefully weighed and mixed with the liquid phase in appropriate powder-to-liquid ratio, packed into silicon molds and aged at $36.5^{\circ} \mathrm{C}$ with $100 \%$ humidity for $24 \mathrm{~h}$.

\subsection{Setting Time Measurement}

The setting time of samples was measured according to ASTM C266-89 using a Gillmore Needles method [18]. Three specimens for each formulation were tested and standard deviation was used as a measure of the standard uncertainty. Initial setting time was determined as the end of moldability and final setting time was choosen as the time beyond which it is possible to touch the cement without serious damage [19].

\subsection{In Vitro Tests}

To assess in vitro bioactivity, the $24 \mathrm{~h}$-set pastes were soaked in simulated body fluid (SBF) at $36.5^{\circ} \mathrm{C}$ [20] for 1,7 and 14 days, after which they were rinsed gently with deionized water, dehydrated with ethanol, and dried.

For degradation tests, the disks were accurately weighed before and after immersion in SBF. The weight loss (WL) was calculated according to

$$
W L \%=\left(W_{0}-W_{d}\right) / W_{d} \times 100
$$

being $W_{0}$ the initial weight of the specimen and $W_{d}$ the weight of the specimen dried after different degradation times ( 7,14 and 21 days). All the measurements were taken in triplicate and the average values were calculated.

\subsection{Cytotoxicity Test for Cements}

The cell viability assay was performed by direct contact test according to ISO 10993-5 using peripheral blood mononuclear cells (PBMCs) and a procedure described elsewhere [21]. Latex $\left(1 \mathrm{~cm}^{2}\right)$ and culture medium were used as positive and negative controls and the number of viable cells was quantitatively assessed by MTT test. Experimental values were analyzed via one-way ANOVA test follow by Tukey's Multiple Comparison Test.

\subsection{Characterization Techniques}

The phase composition of the samples was determined by X-ray diffraction (XRD) in a Philips ${ }^{\circledR} X^{\prime}$ Pert MPD diffractometer equipped with a $\mathrm{Cu}$-target. Diffractograms were recorded employing Ni-filtered radiation $(\lambda=$ $1.5406 \AA$ ) with a step size of $0.05^{\circ}$ and a time/step ratio of 1 second.

The powders' specific surface area was determined by nitrogen gas sorption and obtained by five-point BET analysis using a Nova 1000 surface area analyzer, while the particle size distribution was determined in a CILAS 1180 particle size analyzer using isopropyl alcohol as dispersant.

The morphological variations of materials before and after soaking in SBF were characterized by Scanning Electron Microscopy (SEM) using a JEOL microscope (JSM-6060) on gold-coated samples.

Compressive strength (CS) was measured in a servohydraulic universal testing machine (MTS 810) equipped with a $10 \mathrm{kN}$ load cell, at a loading rate of $1 \mathrm{~mm} / \mathrm{min}$. The number of replicas was $n=10$ and Student's Multiple Comparison Test was performed to compare mean values.

The $\mathrm{pH}$ value was measured during soaking in SBF and readings were taken in an $m \mathrm{PA}-210 \mathrm{pH}$ meter at $36.5^{\circ} \mathrm{C}$. 


\section{RESULTS}

Figure 1 shows the XRD pattern of $\mathrm{CA}$ where the presence of monoclinic $\mathrm{CaAl}_{2} \mathrm{O}_{4}$ (JCPDS 2310-36) as main phase, in addition to dicalcium aluminate $\left[\mathrm{CaAl}_{4} \mathrm{O}_{7}, \mathrm{CA}_{2}\right]$ (JCPDS 2310-37) was found. The specific surface area of the powder was $9.12 \mathrm{~m}^{2} / \mathrm{g}$ and a slight increase to $11.88 \mathrm{~m}^{2} / \mathrm{g}$ was achieved after grinding.

Figure 2 shows the initial and final setting time of $\alpha$-TCP and composites containing different CA mass $\%$. For $\alpha$-TCP-based cement the initial and final setting times were higher than those reported in the literature for similar compositions [22]. With the addition of CA, the setting times increased, this increase being directly proportional to the amount of CA added. There were no significant differences in the final setting times of composites containing $\mathrm{CA}$.

Figures 3-5 show the powder XRD patterns of composites before and after soaking in SBF for 7 and 14 days. For all times and all formulations, the characteristic peaks of $\beta$-TCP (JCPDS 09-0169), which appears as a seconddary phase in $\alpha$-TCP powder (JCPDS 29-0359), were detected. After $24 \mathrm{~h}$ setting (Figure 3), for $\alpha$-TCP-based cement, mainly peaks of CDHA (JCPDS 46-0905) were observed. With the addition of CA, diffraction patterns were very different from those of $\alpha$-TCP-based cement and apparently, only unreacted peaks of $\alpha$-TCP in addition to $\beta$-TCP were present.

After 7 days of soaking (Figure 4) the intensity of $\alpha$-TCP lines decreased in relation to set cements and CDHA lines appeared.

Fourteen days after, the hydration reaction seemed to be complete for $\alpha$-TCP, whereas a great amount of unreacted $\alpha$-TCP, in addition to CDHA, could be observed for

$$
\text { - } \mathrm{CaAl}_{2} \mathrm{O}_{4} \quad \square \mathrm{CaAl}_{4} \mathrm{O}_{7}
$$

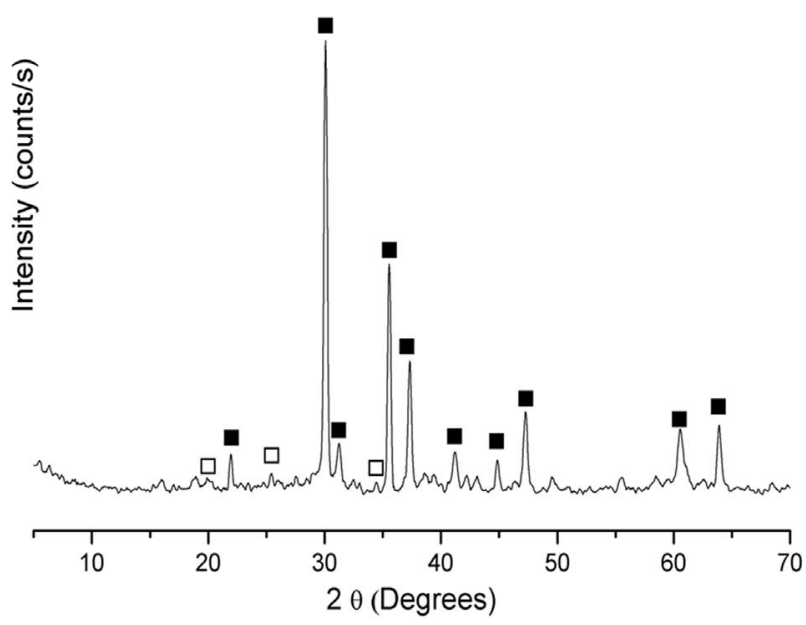

Figure 1. XRD pattern of CA obtained by the pechini route.

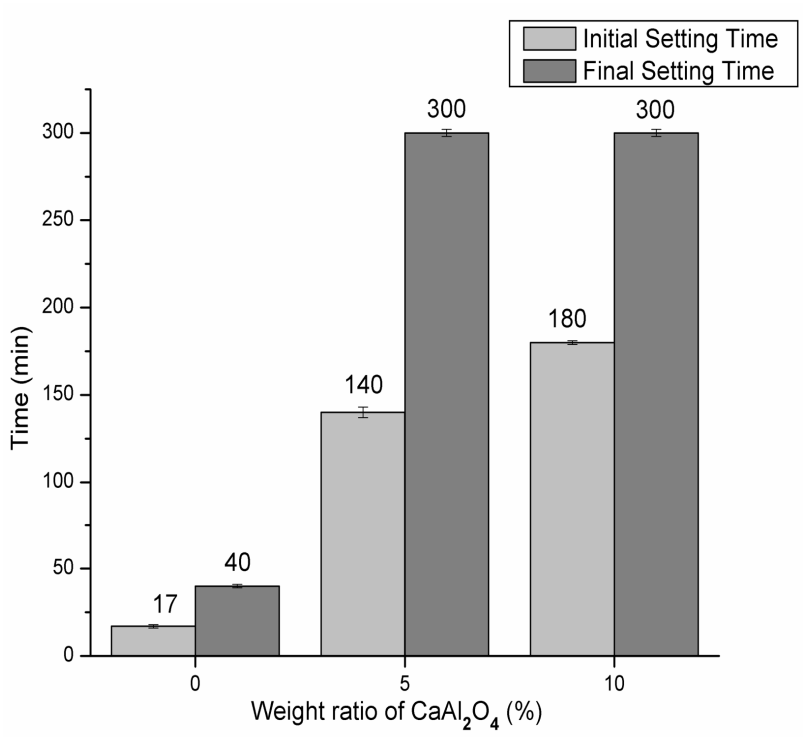

Figure 2. Initial setting and final setting time of the composites compared with $\alpha$-TCP-based cement.

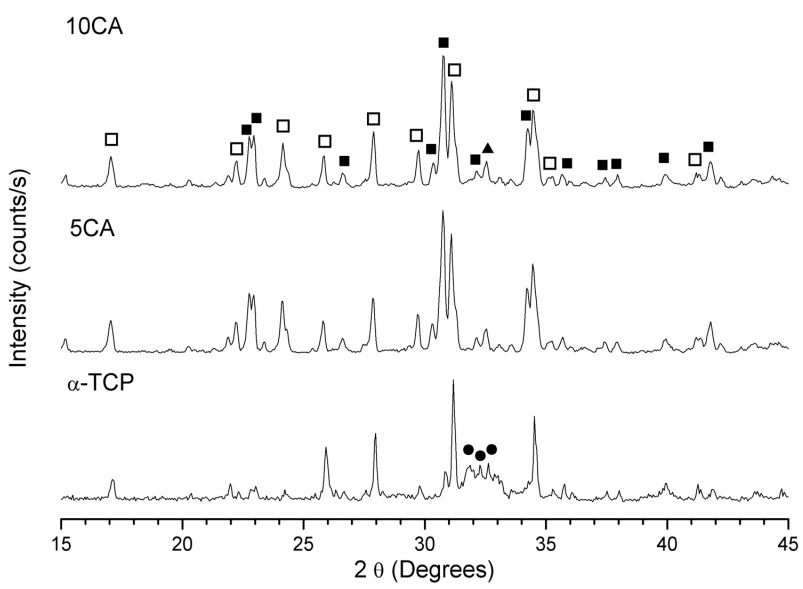

Figure 3. XRD pattern of cement pastes after $24 \mathrm{~h}$ of setting. - $\alpha-\mathrm{Ca}_{3}\left(\mathrm{PO}_{4}\right)_{2} ; \square \beta-\mathrm{Ca}_{3}\left(\mathrm{PO}_{4}\right)_{2} ; \bullet \mathrm{Ca}_{9}\left(\mathrm{HPO}_{4}\right)\left(\mathrm{PO}_{4}\right)_{5}(\mathrm{OH})$.

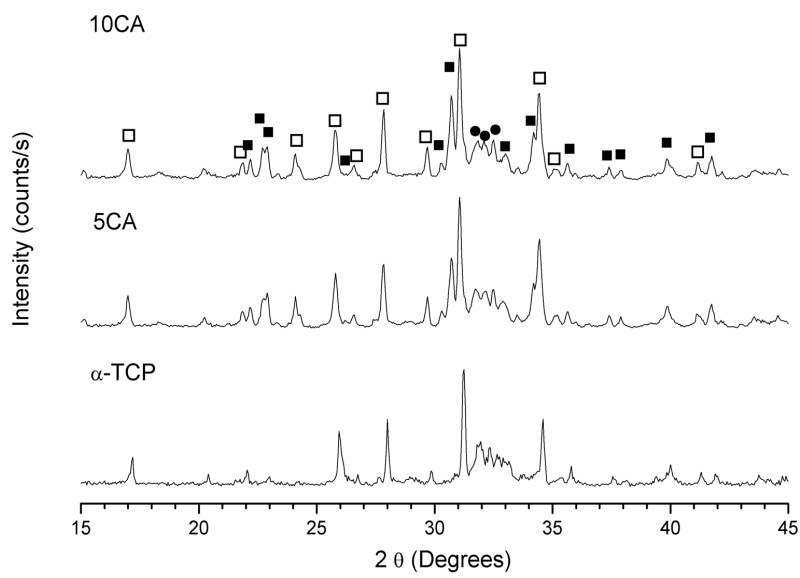

Figure 4. XRD pattern of cement pastes after 7 days of soaking in SBF. $\alpha-\mathrm{Ca}_{3}\left(\mathrm{PO}_{4}\right)_{2} ; \square \beta-\mathrm{Ca}_{3}\left(\mathrm{PO}_{4}\right)_{2} ; \bullet \mathrm{Ca}_{9}\left(\mathrm{HPO}_{4}\right)\left(\mathrm{PO}_{4}\right)_{5}(\mathrm{OH})$. 
composites containing CA (Figure 5). There were no peaks of CA and no proof of the presence of $\mathrm{Ca}_{3} \mathrm{Al}_{2} \mathrm{O}_{6} \cdot 6 \mathrm{H}_{2} \mathrm{O}$ $\left(\mathrm{C}_{3} \mathrm{AH}_{6}\right)(\mathrm{JCPDS} 24-0217)$ or $\mathrm{Al}_{2} \mathrm{O}_{3} \cdot 3 \mathrm{H}_{2} \mathrm{O}\left(\mathrm{AH}_{3}\right)(\mathrm{JCPDS}$ 29-0041), the most likely phases during hydration of CA.

Figure 6 shows the SEM micrographs of the surface of composites after soaking in SBF. For conventional CPC (Figure 6(A)), a superficial layer of CDHA with a globular shape similar to some bioactive materials was deposited within 14 days [23].

Some bacterial contamination by Bacillis and Cocci colonies, represented by spherical and rod-shaped holes, were also observed [24].

For 5CA and 10CA (Figures 6(B) and (C)) small round shaped particles, spherulites-like cristals, of hydroxyapatite, were beginning to deposit on top of the leaf-like intermediary structure since the early stages (about 1day of soaking). Evidence of the formation of a new product con- taining phosphorus was formed on the surface of com- posites was confirmed by EDS analysis (Figure 7).
Figure 8 shows the compressive strength and porosity of $\alpha$-TCP and $\alpha$-TCP/CA composites before and after

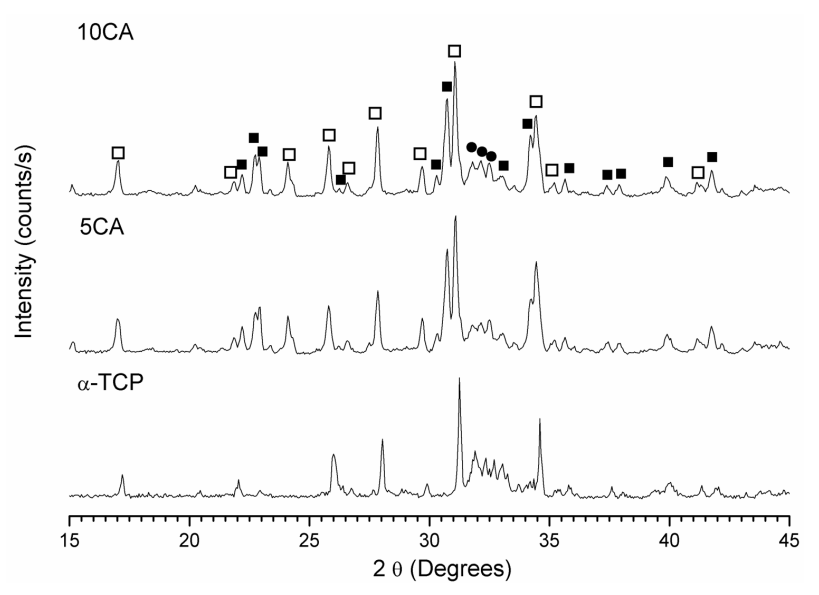

Figure 5. XRD pattern of cement pastes after 14 days of soaking in SBF. $\alpha-\mathrm{Ca}_{3}\left(\mathrm{PO}_{4}\right)_{2} ; \square \beta-\mathrm{Ca}_{3}\left(\mathrm{PO}_{4}\right)_{2} ; \bullet \mathrm{Ca}_{9}\left(\mathrm{HPO}_{4}\right)\left(\mathrm{PO}_{4}\right)_{5}(\mathrm{OH})$.

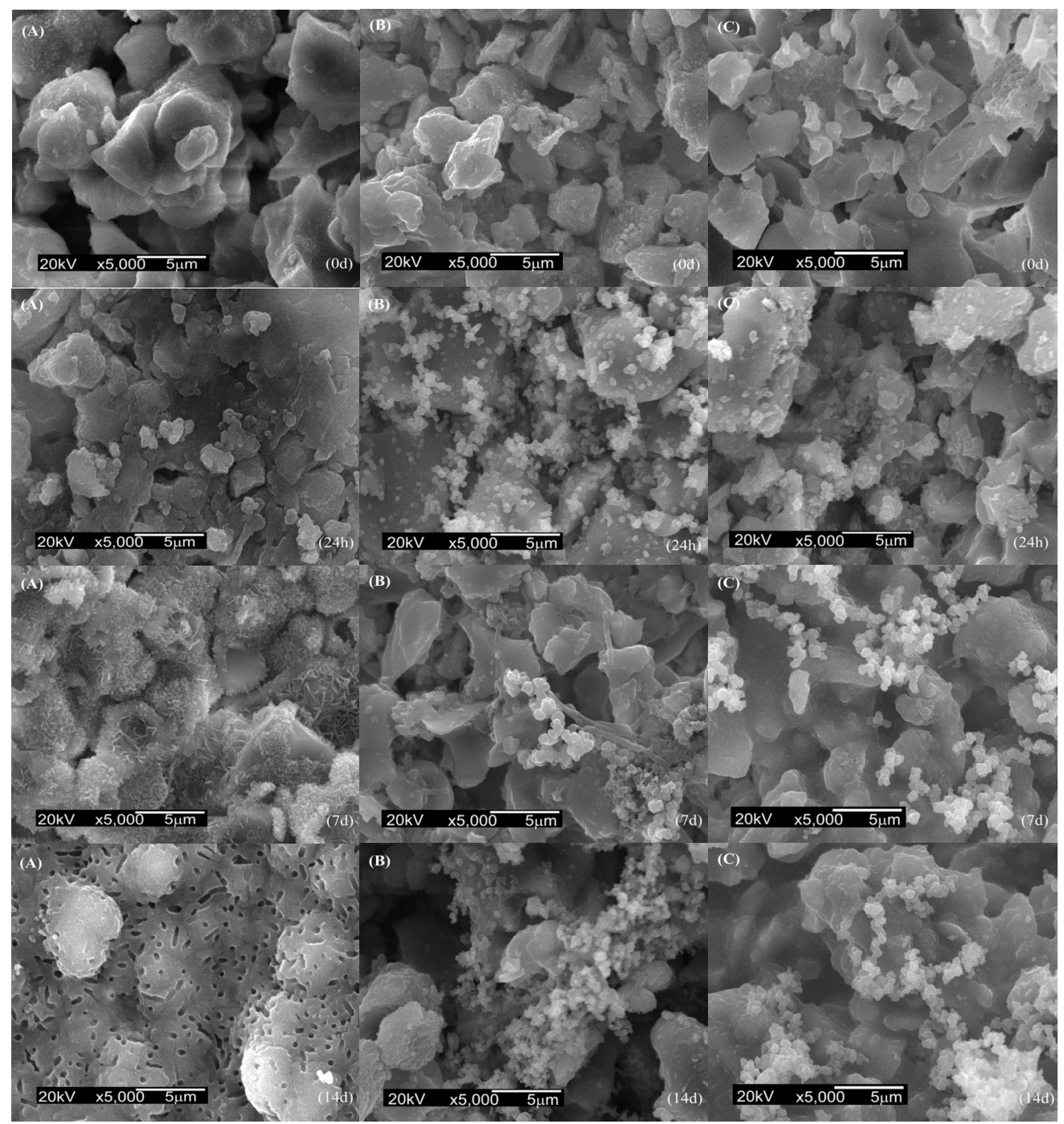

Figure 6. SEM micrographs of the surface after soaking in SBF. (A) $\alpha$-TCP; (B) 5CA; (C) 10CA. 
soaking in SBF for 7 and 14 days. The results indicated that compressive strength of $\alpha$-TCP decreased lightly with soaking, whereas the compressive strength of 5CA and 10CA reached values that did not exceed $5 \mathrm{MPa}$. The porosity of materials containing CA was higher than that of $\alpha$-TCP-based cement for all immersion times.
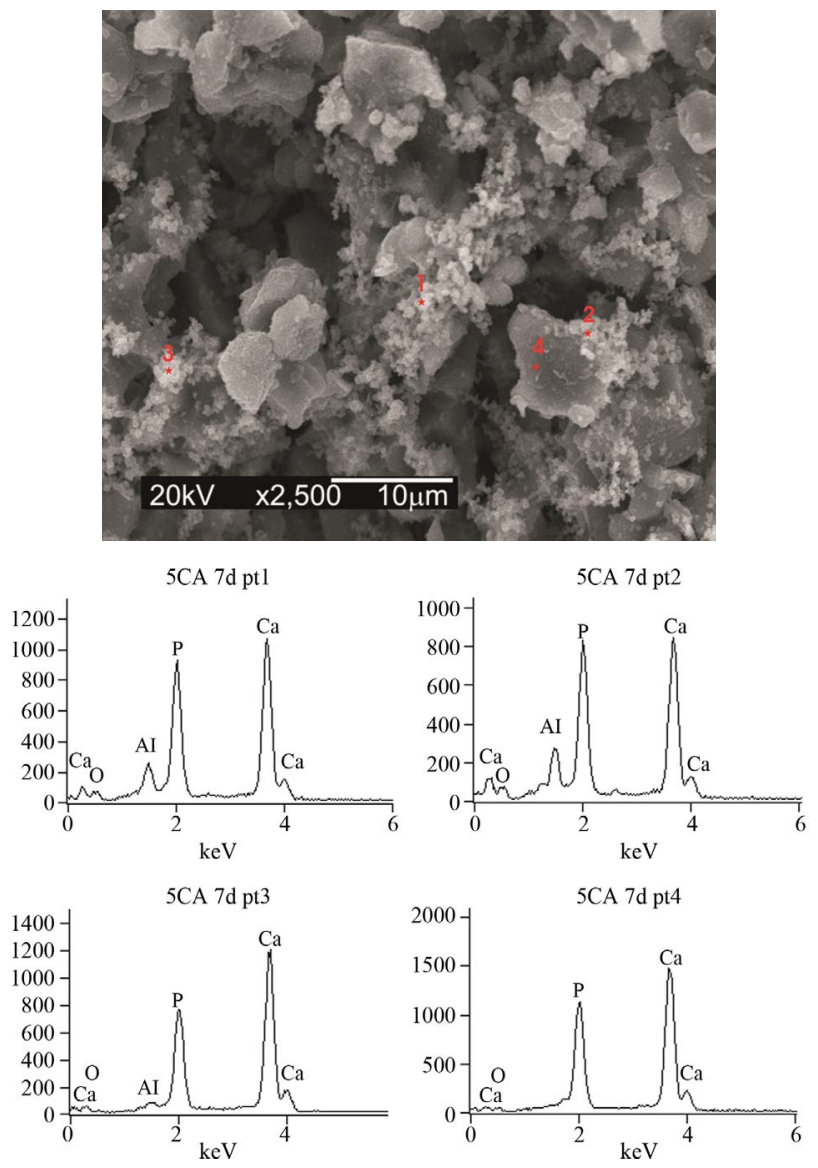

Figure 7. EDS spectrum of 5CA after 7 days of immersion. Punctual analysis.

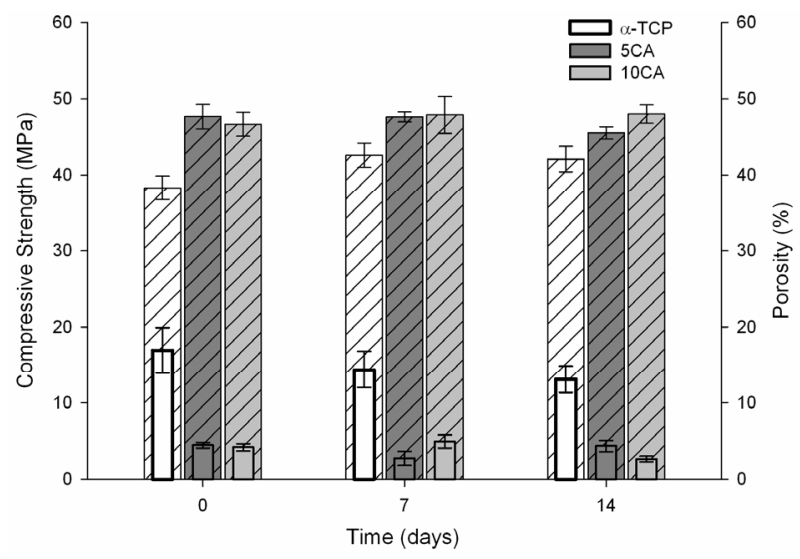

Figure 8. Compressive strength ( $\square$ Solid Bar) and total porosity ( $\boldsymbol{Z}$ Pattern Bar) of the different cement pastes as a function of a time of soaking in SBF solution.
Figure 9 shows the changes in $\mathrm{pH}$ values of $\mathrm{SBF}$ caused by the cement pastes. In the case of $\alpha$-TCP, the $\mathrm{pH}$ increased slightly in the first $24 \mathrm{~h}$ and then dropped to a value close to the physiological $\mathrm{pH}$.

Figure 10 shows the degradation of the $\alpha$-TCP and $\alpha$-TCP/CA composite pastes with different contents of $\mathrm{CA}$ after soaking in SBF solution for various time periods. It was found that the weight of $\alpha$-TCP increased with time, whereas the weight of composites containing CA experienced a mass loss during the first 14 days followed by a mass gain. Also, the degradation rates of composites increase proportional to the amount of CA added and were found to be higher than that of $\alpha$-TCP-based cement.

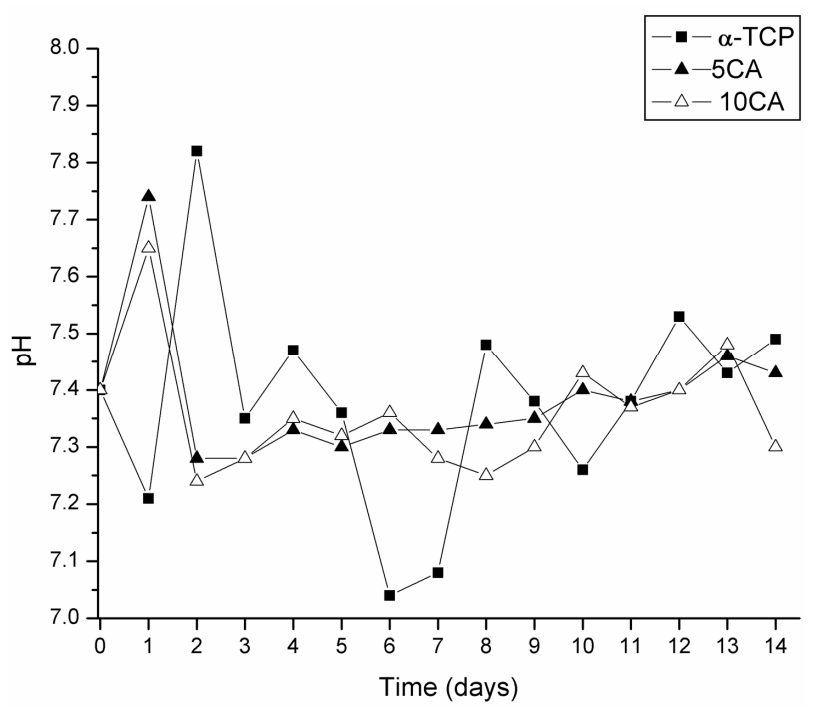

Figure 9. Changes in $\mathrm{pH}$ value of different cement pastes as a function of a time of soaking in SBF solution.

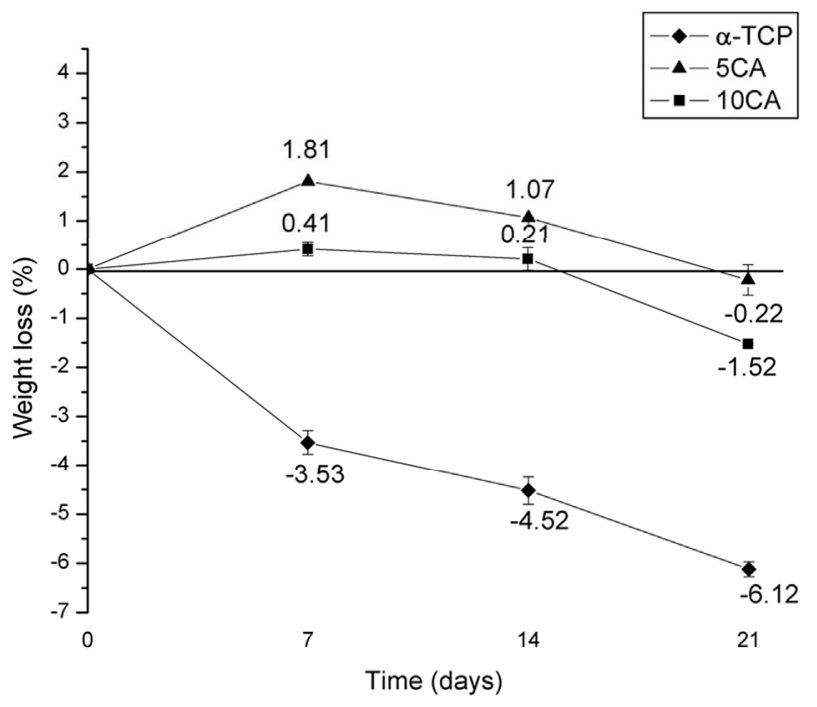

Figure 10. Weight loss of the $\alpha$-TCP and $\alpha$-TCP/CA cement pastes after different soaking times. 
Figure 11 shows the result of cell viability assay of the three composites against the PBMCs after incubation for $24 \mathrm{~h}$ and $48 \mathrm{~h}$. $\alpha$-TCP-based cement and 10CA showed a slight decrease in cell viability when compared to the positive control, although differences were not statisticcally significant. Furthermore, it was found that the viability of PBMCs showed a downward trend in all compositions with aging. Compositions containing calcium aluminate were significantly less citotoxic than positive control at all times; and in the case of 5CA, values similar to the positive control were observed.

\section{DISCUSSION}

The presence of $\mathrm{CA}_{2}$ as a secondary phase has been explained based on the preferential complexing of one of the cations with the polymer, that lead to formation of a char during the burnout process. Due to their higher reactivity, calcium ions preferentially associate themselves with the polymer formed during polyesterification, and are trapped between the chains producing an excess of aluminum ions available at the early stages of the reaction and resulting in the formation of aluminum-rich phases [25]. Once the polymer network is burned, the calcium ions are released and could be reacted with the previously formed $\mathrm{CA}_{2}$ and unreacted aluminum ions to obtain CA (Equations (2), (3)). Some authors have also reported the existence of $\mathrm{CA}_{2}$ as transient phase in high temperature solid state reactions [26].

$$
\begin{gathered}
\mathrm{CaO}+\mathrm{Ca}^{2+}+2 \mathrm{Al}_{2} \mathrm{O}_{3} \stackrel{<900^{\circ} \mathrm{C}}{\longrightarrow} \mathrm{CaAl}_{4} \mathrm{O}_{7}+\mathrm{Ca}^{2+} \\
\mathrm{CaAl}_{4} \mathrm{O}_{7}+\mathrm{Ca}^{2+} \stackrel{+\mathrm{O}_{2} \geq 900^{\circ} \mathrm{C}}{\longrightarrow} 2 \mathrm{CaAl}_{2} \mathrm{O}_{4}
\end{gathered}
$$

Setting times for calcium phosphates usually ranged from 5 to 8 minutes when a neutral phosphate such as disodium hydrogen phosphate $\left(\mathrm{Na}_{2} \mathrm{HPO}_{4}\right)$ or sodium dihydrogen

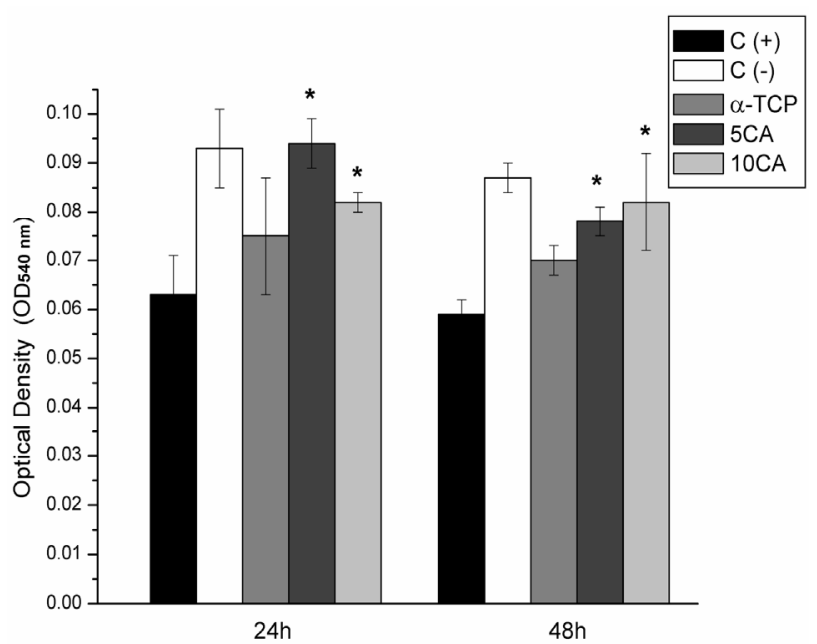

Figure 11. Cell viability of the PBMCs on the different pastes after culturing for 24 and $48 \mathrm{~h}, * \mathrm{p}<0.05$ compared with $(+)$ control group. phosphate $\left(\mathrm{NaH}_{2} \mathrm{PO}_{4}\right)$ is used [22]. When $\beta$-TCP is present, setting times are often delayed as it does not take part in the hydration reaction [27]. Furthermore, the solubility of $\alpha$-TCP decreases with the addition of CA, due to the formation of a calcium aluminate hydrate gel on the surface of $\alpha$-TCP particles during $\mathrm{CaAl}_{2} \mathrm{O}_{4}$ hydrolysis (Equation (4)) thus retarding CDHA precipitation.

$$
\mathrm{Ca}\left(\mathrm{AlO}_{2}\right)_{2}+4 \mathrm{H}_{2} \mathrm{O} \Leftrightarrow \mathrm{Ca}^{2+}+2 \mathrm{Al}(\mathrm{OH})_{4}^{-}
$$

On the other hand, when mixed with water calcium aluminates react in an acid-base reaction where the ceramic powder works as the base and water as the weak acid. The dissolution continues until saturation and the ensuing later precipitation of less soluble hydrates, initially in the form of amorphous gel, which then grow up until they meet each other and a skeleton (a connected cluster of hydrates) of hydrates is built up continuously. In the presence of phosphates salts, $\mathrm{PO}_{4}{ }^{3-}$ ions react with $\mathrm{Ca}^{2+}$ from Equation (4) to form insoluble salts, such as amorphous calcium phosphate (ACP) or CDHA, that precipitate on the surface of cement particles to create a layer that hinders the hydration reaction of $\alpha$-TCP, thus retarding the setting times [28]. Moreover, it is generally accepted that the presence of $\mathrm{Na}^{+}$ions in the medium also delays the setting times even though the role of metal ions as retarders is controversial and not very significant.

Another factor that may influence the setting time is the nature and solubility of the hydrates formed. For pure $\mathrm{CA}$ the hydration mechanism most widely accepted is the one that favors the precipitation of the more soluble hydrate, which requires a higher nucleation time and therefore, delays the setting times.

With the addition of CA, and the delay in setting times, the formation of CDHA as a result of the transformation $\alpha$-TCP $\rightarrow$ CDHA (Equation (5)) is retarded and peaks of unreacted $\alpha$-TCP appeared as main crystalline phase (Figure 3). Since the hydration mechanism of $\alpha$-TCP-based cements is dependent on the diffusion of the reactive species through the layer of formed product, the degree of extension of the $\alpha$-TCP hydration is lower in the presence of CA as evidenced by the unreacted peaks in the diffraction patterns after 7 and 14 days (Figures 4 and 5).

The intensity of $\beta$-TCP peaks remains constant through the experiment because it is not involved in the hydration reaction; and no evidence of the presence of calcium aluminates hydrates Katoite $\left[\mathrm{Ca}_{3} \mathrm{Al}_{2}(\mathrm{OH})_{12} ; \mathrm{C}_{3} \mathrm{AH}_{6}\right]$ and Gibbsite $\left[\mathrm{Al}(\mathrm{OH})_{3}, \mathrm{AH}_{3}\right]$ was found (Equation (6)), probably due to the small amount present and the amorphous character of the same.

$$
\begin{gathered}
3 \alpha-\mathrm{Ca}_{3}\left(\mathrm{PO}_{4}\right)_{2(\mathrm{~s})}+\mathrm{H}_{2} \mathrm{O}=\mathrm{Ca}_{9}\left(\mathrm{HPO}_{4}\right)\left(\mathrm{PO}_{4}\right)_{5} \mathrm{OH}_{(\mathrm{s})}(5) \\
3 \mathrm{CaO} \cdot \mathrm{Al}_{2} \mathrm{O}_{3(\mathrm{~s})}+12 \mathrm{H}_{2} \mathrm{O} \stackrel{37^{\circ} \mathrm{C}}{\longrightarrow} \\
\mathrm{Ca}_{3}\left[\mathrm{Al}(\mathrm{OH})_{4}\right]_{2}(\mathrm{OH})_{4(\mathrm{~s})}+4 \mathrm{Al}(\mathrm{OH})_{3(\mathrm{~s})}
\end{gathered}
$$


A bioactive material is that which is capable of providing a chemical integration with living tissue through the biomineralization of bone mineral phase at the material tissue interface composed of a calcium phosphate layer $[29,30]$. When compared with others bioactive bone substitution materials such as glasses or A-W glass ceramic; the CPCs appear to be less capable of inducing a homogeneous bone-like apatite layer on the surface to form a chemical bond with bone tissue at early stages of implantation. The deposition of apatite on the surface of calcium phosphate cement is largely dependent on supersaturation of $\mathrm{Ca}^{2+}$ and $\mathrm{PO}_{4}{ }^{3-}$ ions. Such process is indeed slow, which accounts for the absence of homogeneous apatite layer formation at early stages [23]. The presence of HA on the surface of composites after 1 day of soaking could be explained on the basis of the formation of the $\mathrm{Ca}_{3}\left[\mathrm{Al}(\mathrm{OH})_{4}\right]_{2}(\mathrm{OH})_{4}$ that's works as nuclei sites during $\mathrm{CA}$ hydration. The $\mathrm{Ca}^{2+}$ and $\mathrm{Al}(\mathrm{OH})^{4-}$ ions released from $\mathrm{CA}$ into the $\mathrm{SBF}$ solution precipitate via ion exchange with the $\mathrm{H}_{3} \mathrm{O}^{+}$in the form of a hydroxyl layer that provides seeds for HA nucleation and posterior precipitation and crystal growth by consuming calcium and phosphorus ions in the SBF solution. The greater the soaking time, the larger the portion of the surface area covered reaching all surfaces after longer times of immersion without significant changes in microstructure according to $\mathrm{Oh}$ et al. [31,32].

No bacterial growth was observed when CA was added to the $\alpha$-TCP-based cement. This may be related to the release of hydroxyl ions (Equation (7)), which creates an environment unfavorable for bacterial growth as a result of the $\mathrm{pH}$ increase.

$$
\mathrm{Al}(\mathrm{OH})_{4}^{-} \Leftrightarrow \mathrm{Al}^{3+}+4 \mathrm{OH}^{-}
$$

A critical problem that prevents a wider clinical application of the CPCs is their mechanical properties; mainly their intrinsic porosity which seems to be the cause for their low compressive strength. After setting, CPC usually shows a total porosity of $40-50 \mathrm{wt} \%$ [22] whereas the porosity of pure CAC is usually $18 \%$ [33]. In both cases, final porosity depends on intrinsic porosity, which strongly depends on the $\mathrm{L} / \mathrm{P}$ ratio and the particle size of the starting powder particle [34], and the mixing process (air bubbles from handling). For $\alpha$-TCP/CA composites, a larger $\mathrm{L} / \mathrm{P}$ ratio was necessary to allow an adequate flow of the cement paste to the detriment of the final porosity of materials and consequently the final mechanical strength. During hydration, the space occupied by the liquid during the hardening process is replaced by hydrates to obtain a high strength body and for CAC and this consumption is higher than for conventional CPCs. On the other hand, over time, the less stable hydrates initially formed, subsequently transform into a mixture of $\mathrm{Ca}_{3} \mathrm{Al}_{2}(\mathrm{OH})_{12} ; \mathrm{Al}(\mathrm{OH})_{3}$ gel and $\mathrm{H}_{2} \mathrm{O}$, which cause an increase in porosity that can be accompanied by a decrease in strength due to the loss of water [35]. Large aggregates may also have a negative impact on the strength, acting as defects in the structure and producing high standard deviations of the strength values.

When immersed in SBF, the $\mathrm{pH}$ of the $\alpha$-TCP-based cement decreases to values close to 7.0, probably due to the formation of some $\mathrm{H}_{3} \mathrm{PO}_{4}$ during hydrolyzation of $\mathrm{Ca}_{3} \mathrm{PO}_{4}$ into $\mathrm{Ca}_{10}\left(\mathrm{PO}_{4}\right)_{6}(\mathrm{OH})_{2}$ [36] and values remain mostly unchanged henceforth. With the addition of CA, $\mathrm{OH}^{-}$ions are released into the SBF solution raising its $\mathrm{pH}$ in the first $24 \mathrm{~h}$ after this the $\mathrm{pH}$ stabilizes which indicates that $\mathrm{OH}^{-}$ions are no longer released to the medium. The presence of an amorphous calcium phosphate gel, identified by XRD [16], was observed in the supernatant solution during the first $24 \mathrm{~h}$, indicating the early nucleation of the phase but no precipitation, maybe due to the increment in local $\mathrm{pH}$ at initial stages as a consequence of the release of $\mathrm{OH}^{-}$ions.

The dissolution of calcium ions into body fluids plays an important role in the nucleation and growth of hydroxyapatite layers on a material's surface as it raises the degree of supersaturation of the surrounding fluid with respect to HA. Conventional CPCs usually have a slow degradability and often experience a mass gain after long periods of soaking as a result of hydrolysis of $\alpha$-TCP or due to the formation of apatite on the surface of the samples [37]. With the addition of CA, a greater amount of $\mathrm{Ca}^{2+}$ ions would dissolve more quickly into the environment creating micropores on the surface of the composite cement and increasing the contact area of the cement with the solution of SBF and also the rate of dissolution as a result [38]. After 14 days, the amount of apatite deposited on the cement surface and formed due to the hydrolysis of $\alpha$-TCP was larger than that of the dissolution of CA, so the weight of samples increases. The greater the amount of CA added, the greater the degree of degradation of composites.

The first level of testing in the evaluation of biocompatibility of biomaterials is the determination of in vitro cytotoxicity. Although it is known that large amounts of aluminium ions could be toxic [39], the addition of CA to these formulations did not increase the toxicity of the composite, once the amount added does not produce a detectable release of $\mathrm{Al}^{3+}$ ions to the medium [13]. The results of cell culture showed that composites containing $\mathrm{CA}$ are less cytotoxic and more compatible than pure $\alpha$ TCP-based cement. This could be attributed to the early precipitation of small round shaped particles, spheruliteslike cristals, of hydroxyapatite on the top of the structure during soaking in SBF solution. The increase in cytotocixity after $48 \mathrm{~h}$ could be explained on the basis of: 1) chemical changes in materials during culturing that may have led to a greater change in the $\mathrm{pH}$ of the culture me- 
dium, resulting in more cellular damage (represented by reduced viability), and 2) an increase in the release of some material components that did not occur initially, rendering the material more cytotoxic over time [40].

\section{CONCLUSIONS}

In this paper, novel composite cements were prepared by adding $\mathrm{CaAl}_{2} \mathrm{O}_{4}$ into the traditional $\alpha-\mathrm{Ca}_{3}\left(\mathrm{PO}_{4}\right)_{2}$-based cement. The composites thus obtained showed an increase in setting times and a considerable delay in the rate of $\alpha$-TCP hydration, which combined with the increase in porosity to cause a loss in the mechanical properties. Furthermore, the presence of CA compromises the precipitation of CDHA and increases the degradability of cements. However, the $\alpha$-TCP/CA composites showed the precipitation of hydroxyapatite at early stages and were not only more biocompatible but also more non-cytotoxic as confirmed by the in vitro cytotoxic assay.

Based on the findings of this study, new experiments are now in process in order to control the setting properties and the degree of extension of the $\alpha$-TCP hydration with the aim of improving the mechanical properties of the com- posites.

\section{ACKNOWLEDGEMENTS}

This work was conducted with support from CAPES, the Brazilian Government entity dedicated to the training of human resources.

\section{REFERENCES}

[1] Brown, W.E. and Chow, L.C. (1986) A new calcium phosphate water-setting cement. In: Brown, W.E., Ed., Cements Research Progress, The Society in Columbus, Westerville, 352-379.

[2] LeGeros, R.Z., Chohayeb, A. and Shulman, A. (1982) Apatitic calcium phosphates: Possible dental restorative materials. Journal of Dental Research, 61, 343.

[3] Monma, H. (1976) The hydration of alpha-tricalcium phosphate, Yogo-Kyokai-Shi, 84, 209-213. doi:10.2109/jcersj1950.84.968_209.

[4] Ginebra, M.P., Boltong, Fernández, M.G.E., Planell, J.A., and Driessens, F.C.M. (1995) Effect of various additives and temperature on some properties of an apatitic calcium phosphate cement. Journal of Material Science: Materials in Medicine, 6, 612-616. doi:10.1007/BF00134332.

[5] Santos, L.A., de Oliveira, L., Cristina da Silva, E., Garcia, R., Ortega, A. and Arruda, A (2000). Fiber reinforced calcium phosphate. Artificial Organs, 24, 212-216. doi:10.1046/j.1525-1594.2000.06541.x.

[6] Yamamoto, H., Niwa, S., Hori, M., Hattori, T., Sawai, K., Aoki, S., Hirano, M. And Takeuchi, H. (1998) Mechanical strength of calcium phosphate cement in vivo and in vitro. Biomaterials, 19, 1587-1591. doi:10.1016/S0142-9612(97)00121-X.

[7] Dorozhkin, S. (2009) Calcium orthophosphate cements and concretes. Materials, 2, 221-291. doi: $10.3390 / \mathrm{ma} 2010221$.

[8] Ishikawa, K. and Asaoka, K. Estimation of ideal mechanical strength and critical porosity of calcium phosphate cement. Journal of Biomedical Material Research, 29, 1537-1543. doi:10.1002/jbm.820291210.

[9] Kraft, L. and Hermansson, L. (2003) Dimension stable binding agent system for dental application. US Patent No. 6620232 .

[10] Roemhildt, M.L., Wagner, S.D. and McGee, T.D. (2006) Characterization of novel calcium phosphate composite bone cement: Flow, setting, and aging properties. Journal of Material Science: Materials in Medicine, 17, 11271132. doi:10.1007/s10856-006-0539-2.

[11] Engqvist, H., Persson, T., Lööf, J., Faris,A. and Hermansson, L. (2008) Chemical stability of a novel injectable bioceramic for stabilization of vertebral compression fractures. Trends Biomaterials \& Artificial Organs, 21, 98-106.

[12] Lööf, J. (2008) Calcium aluminate as biomaterial: Synthesis, design and evaluation. Ph.D. Thesis, Uppsala Universitet, Uppsala.

[13] Morejón-Alonso, L., Santos, L.A., García, R.G. (2009) Influence of mixing liquid on the properties of calcium aluminate cement. Key Engineering Materials, 396-398, 241-244. doi:10.4028/www.scientific.net/KEM.396-398.241.

[14] MGee, T.D. and Roemhildt, M.L. (2004) US Patent No. 6723334.

[15] Bermudez, O., and Boltong, M.G., Driessens, F.C.M. and Planell, J.A. (1994) Development of some calcium phosphate cements from combinations of $\alpha$-TCP, MCPM and $\mathrm{CaO}$. Journal of Material Science: Materials in Medicine, 5, 160-163.

[16] Morejón-Alonso, L. (2011) Avaliação de cimentos ósseos de fosfatos de cálcio com adições de aluminato e silicato de cálcio. Ph.D. Thesis, Universidade Federal do Rio Grande do Sul, Porto Alegre.

[17] Gaki, A., Chysafi, R. and Kakali, G. (2007) Wet chemical synthesis of monocalcium aluminate. Journal of the European Ceramic Society, 27, 1785-1789. doi:10.1016/j.jeurceramsoc.2006.05.006.

[18] C-266-89 (1995) A. Standart test method for time of setting of hydraulic-cement paste by Gillmore needles.

[19] Driessens, F.M.C., Planell, J.A. and Gil, X. (1995) Calcium phosphates bone cements. In: Wise, D., Trantolo, D., Altobelli, D., Yaszernski, M., Gresser, J. and Schwartz, E., Eds., Encyclopedic handbook of biomaterials and bioengineering Part B: Applications, New York, 855871.

[20] Kim, H.M., Miyazaki, T., Kokubo, T. and Nakamura, T. (2001) Revised simulated body fluid. Key Engineering Materials, 192-195, 47-50.

doi:10.4028/www.scientific.net/KEM.192-195.47.

[21] Morejón-Alonso, L., Ferrari, M.B., Camassola, M., Garcia, R. and Santos, L.A. (2010) In vitro citotoxicity of a calcium phosphate-silicate composite bone cement. Proceedings of the 6th Congresso Latinoamericano de 
Órgãos Artificiais e Biomateriais, 17-20 August 2010, Gramado.

[22] Ambard, A. and Mueninghoff, L. (2006) Calcium phosphate cement: Review of mechanical and biological properties. Journal of Prosthodontics, 15, 321-328. doi:10.1111/j.1532-849X.2006.00129.x.

[23] Kokubo, T. and Takadama, H. (2006) How useful is SBF in predicting in vivo bone bioactivity? Biomaterials, 27, 2907-2915. doi:10.1016/j.biomaterials.2006.01.017.

[24] Gil, J., Padrós, A., Manero, J., Aparicio, M.C., Nilsson, M. and Planell, J.A. (2002) Growth of bioactive surfaces on titanium and its alloys for orthopedic and dental implants. Materials Science and Engineering, 22, 53-60. doi:10.1016/S0928-4931(01)00389-7

[25] Gülgun, M., Popoola, O. and Kriven, W. (1994) Chemical synthesis and characterization of calcium aluminate powders. Journal of the American Ceramic Society, 77, 831-839.

[26] Rivas, J.M., De Aza, A.H. and Pena, P. (2005) Synthesis of $\mathrm{CaAl}_{2} \mathrm{O}_{4}$ from powders: Particle size effect. Journal of the European Ceramic Society, 25, 3269-3279. doi:10.1016/j.jeurceramsoc.2004.06.021.

[27] Ginebra, M.P., et al. (1997) Setting reaction and hardening of an apatitic calcium phosphate cement. Journal of Dental Research, 76, 905-912. doi:10.1177/00220345970760041201.

[28] Garcia, J.R., de Oliveira, I.R. and Pandolfelli, V.C. (2007) Processo de hidratação e os mecanismos de atuação dos aditivos aceleradores e retardadores de pega do cimento de aluminato de cálcio. Cerâmica, 53, 42-56.

[29] Greenspan, D.C. (1999) Bioactive ceramic implant materials. Current Opinion in Solid State \& Material Science, 4, 389-393. doi:10.1016/S1359-0286(99)00021-2.

[30] Kim, H.M. (2003) Ceramic bioactivity and related biomimetic strategy. Current Opinion in Solid State \& Material Science, 7, 289-299. doi:10.1016/j.cossms.2003.09.014.

[31] Oh, S.H., Finones, R., Jin, S., Choi, S.Y. and Kim, K.N. (2004) Influence of tricalcium aluminate phase on in vitro biocompatibility and bioactivity of calcium aluminate bone cement. Journal of Materials Research, 19, 10621067. doi:10.1557/JMR.2004.0139.

[32] Oh, S., Choi, S.Y., Lee, Y., Kim, K. and Choi, S.H. (2003) Effects of lithium fluoride and maleic acid on the bioactivity of calcium aluminate cement: Formation of hydroxyapatite in simulated body fluid. Journal of Biomedical Material Research, 67, 104-111.

[33] Oliveira, I.R., Pandolfelli, V.C. and Jacobovitz, M. (2010) Chemical, physical and mechanical properties of a novel calcium aluminate endodontic cement. International Endodontic Journal, 43, 1-8. doi:10.1111/j.1365-2591.2010.01770.x.

[34] Fukase, Y., Eanes, E.D., Takagi, S. and Chow, L.C. (1990) Setting reactions and compressive strengths of calcium phosphate cements. Journal of Dental Research, 69, 1852-1856. doi:10.1177/00220345900690121201.

[35] Lea, F.M. (1970) The chemistry of cement and concrete. Edward Arnold Ltd., London.

[36] Santos, L.A., García, R., Rogero, S.O., Higa, O.Z., Boschi, A.O. and de Arruda, A.C.F. (2002) $\alpha$-Tricalcium phosphate cement: in vitro cytotoxicity. Biomaterials, 23, 2035-2042. doi:10.1016/S0142-9612(01)00333-7.

[37] Ishikawa, K., Takagi, S., Chow, L.C., Ishikawa, Y., Eanes, E.D. and Asaoka, K. (1994) Behavior of a calcium phosphate cement in simulated blood plasma in vitro. Dental Materials, 10, 26-32. doi:10.1016/0109-5641(94)90018-3.

[38] Guo, H., Wei, J. and Liu, C.S. (2006) Development of a degradable cement of calcium phosphate and calcium sulfate composite for bone reconstruction. Biomedical Materials, 1, 193-197. doi:10.1088/1748-6041/1/4/003.

[39] Banasik, A., and Lankoff, A. (2001) The effect of aluminium on the stability of intracellular membranes. Cellular Biology Molecular Letter, 6, 384.

[40] Julien, M., et al. (2007) Physico-chemical-mechanical and in vitro biological properties of calcium phosphate cements with doped amorphous calcium phosphates. Biomaterials, 28, 956-965. doi:10.1016/j.biomaterials.2006.10.018 